\title{
Compressive Strength, Microstructure and Hydration Products of Hybrid Alkaline Cements
}

\author{
Zahra Abdollahnejad ${ }^{\mathrm{a}}$, Petr Hlavacek ${ }^{\mathrm{b}}$, Sergio Miraldo ${ }^{\mathrm{a}}$, Fernando Pacheco-Torgal ${ }^{\mathrm{*}}$, \\ José Luís Barroso de Aguiar \\ ${ }^{a} C$-TAC Research Centre, University of Minho, Guimarães, Portugal \\ ${ }^{\mathrm{b}}$ Czech Technical University in Prague, Prague, Czech Republic \\ ${ }^{ }$Department of Civil Engineering, University of Minho, Guimarães, Portugal
}

Received: September 1, 2013; Revised: April 8, 2014

\begin{abstract}
Ordinary Portland cement (OPC) is the dominant binder in the construction industry with a global production that currently reaches a total of $3 \mathrm{Gt}$ per year. As a consequence, the cement industry's contribution to the total worldwide $\mathrm{CO}_{2}$ emissions is of about $7 \%$ of the total emissions. Publications on the field of alkali-activated binders (also termed geopolymers), state that this new material is, potentially, likely to become an alternative to Portland cement. However, recent LCA studies show that the environmental performance of alkali-activated binders depends, to great extent, of their composition. Also, researchers report that these binders can be produced in a more eco-efficient manner if the use of sodium silicate is avoided. This is due to the fact that the referred component is associated to a high carbon footprint. Besides, most alkali-activated cements suffer from severe efflorescence, a reaction originated by the fact that the alkaline and/or soluble silicates that are added during processing cannot be totally consumed. This paper presents experimental results on hybrid alkaline cements. The compressive strength results and the efflorescence observations show that some of the new mixes already exhibit a promising performance.
\end{abstract}

Keywords: hybrid alkaline cements, compressive strength, efflorescences, microstructure

\section{Introduction}

Ordinary Portland cement (OPC) is the dominant binder in the construction industry with an annual production of almost $3 \mathrm{Gt}^{1}$. Additionally, the production of one tonne of OPC generates 0.55 tonnes of chemical $\mathrm{CO}_{2}$ and requires an additional 0.39 tonnes of $\mathrm{CO}_{2}$ in fuel emissions for the baking and grinding activities, resulting in a total of 0.94 tonnes of $\mathrm{CO}_{2}$. In 2000, the cement industry emitted, on average, $0.87 \mathrm{~kg}$ of $\mathrm{CO}_{2}$ for every $1 \mathrm{~kg}$ of cement produced $^{2}$. As a consequence, this industry contributes to about $7 \%$ of the total worldwide $\mathrm{CO}_{2}$ emissions ${ }^{3}$. It is also expected that the global demand of OPC will have a twofold increase by the year 2050, reaching a total of $6 \mathrm{Gt} / \mathrm{year}$. The urge to reduce carbon dioxide emissions, and also, the fact that OPC structures built a few decades ago are still facing disintegration problems points out the handicaps of OPC. Additionally, Portland cement based concrete presents higher permeability, allowing water and other aggressive media to enter, further leading to carbonation and corrosion issues. The early deterioration of reinforced concrete structures based on OPC is a current phenomenon of significant consequences, both in terms of the cost for the rehabilitation of these structures and as a result of the environmental impacts associated with these operations. Investigations $^{4-8}$ carried out so far in the development of alkali activated binders (also termed geopolymers) showed that much has already been investigated, and also, that

*e-mail: f.pachecotorgal@gmail.com an environmentally friendly alternative to OPC is rising. According to Davidovits ${ }^{9}$, geopolymer production generates just 0.184 tons of $\mathrm{CO}_{2}$ per ton of binder. These findings, however, were not confirmed by Duxson et al. ${ }^{10}$. These authors stated that, although the $\mathrm{CO}_{2}$ emissions generated during the production of $\mathrm{Na}_{2} \mathrm{O}$ are very high, the production of geopolymers is still associated with a level of carbon dioxide emissions lower than the emissions generated in the production of OPC. Meanwhile, an independent study made by Zeobond Pty LtD concluded that the former was responsible for $80 \%$ lower $\mathrm{CO}_{2}$ emissions ${ }^{11}$. Weil et al. ${ }^{12}$ compared Portland cement concrete to geopolymeric concrete possessing similar durability reporting that the latter implies $70 \%$ lower $\mathrm{CO}_{2}$ emissions, all of which confirming the aforementioned reductions. McLellan et al. ${ }^{13}$, in turn, reported a 44 to $64 \%$ reduction in greenhouse gas emissions of geopolymers when compared to OPC. Habert et al. ${ }^{14}$ confirmed that they are responsible for lower impacts on global warming when compared to OPC but, on the other hand, demonstrate higher environmental impacts regarding other impact categories. Lower $\mathrm{CO}_{2}$ emissions geopolymers are therefore needed. Nevertheless, the durability of geopolymers is still the subject of some controversy ${ }^{15}$. In fact, in his research, Duxson et al. ${ }^{10}$ stated that this is the most important issue when determining the success of these new materials. Other authors ${ }^{16}$, mentioned that the fact that samples from the former Soviet Union, which have been exposed to service conditions for an 
excess of 30 years, show little degradation, means that geopolymers do therefore appear to stand the test of time. However, since those materials were of the $(\mathrm{Si}+\mathrm{Ca})$ type, that conclusion cannot be extended to geopolymers, defined as an "alkali aluminosilicate gel, with aluminium and silicon linked in a tetrahedral gel framework" 11 . On the other hand, Juenger et al. ${ }^{1}$ argue that "The key unsolved question in the development and application of alkali activation technology is the issue of durability", and more recently, Van Deventer et al. ${ }^{17}$ recognized that "whether geopolymer concretes are durable remains the major obstacle to recognition in standards for structural concrete". Efflorescences are an important drawback of two part geopolymers and, so far, have received very little attention. According to Skvara et al. ${ }^{18,19}$, the bond between the sodium ions $\left(\mathrm{Na}^{+}\right)$and the aluminosilicate structure is weak, thus explaining the leaching behaviour. Kani et al. ${ }^{20}$ showed that efflorescences can be reduced either by the addition of alumina-rich admixtures or by hydrothermal curing at temperatures of $65^{\circ} \mathrm{C}$ or higher. These authors found that the use of $8 \%$ of calcium aluminate cement greatly reduces the mobility of alkalis and leads to minimum efflorescences (this

Table 1. Bibliographic history of some important alkali-activated cement/geopolymer related events ${ }^{6}$.

\begin{tabular}{|c|c|c|}
\hline Feret & 1939 & Slags used for cement. \\
\hline Purdon & 1940 & Alkali-slag combinations. \\
\hline Glukhovsky & 1959 & Theoretical basis and development of alkaline cements. \\
\hline Glukhovsky & 1965 & First called "alkaline cements". \\
\hline Davidovits & 1979 & "Geopolymer" term. \\
\hline Malinowski & 1979 & Ancient aqueducts characterized. \\
\hline Forss & 1983 & F-cement (slag-alkali-superplasticizer). \\
\hline Langton and Roy & 1984 & Ancient building materials characterized. \\
\hline Davidovits and Sawyer & 1985 & Patent of "Pyrament" cement. \\
\hline Krivenko & 1986 & DSc thesis, $\mathrm{R}_{2} \mathrm{O}-\mathrm{RO}-\mathrm{SiO}_{2}-\mathrm{H}_{2} \mathrm{O}$. \\
\hline Malolepsy and Petri & 1986 & Activation of synthetic melilite slags. \\
\hline Malek et al. & 1986 & Slag cement-low level radioactive wastes forms. \\
\hline Davidovits & 1987 & Ancient and modern concretes compared. \\
\hline Deja and Malolepsy & 1989 & Resistance to chlorides shown. \\
\hline Kaushal et al. & 1989 & Adiabatic cured nuclear wastes forms from alkaline mixtures. \\
\hline Roy and Langton & 1989 & Ancient concretes analogs. \\
\hline Majundar et al. & 1989 & $\mathrm{C}_{12} \mathrm{~A}_{7}$-slag activation. \\
\hline Talling and Brandstetr & 1989 & Alkali-activated slag. \\
\hline Wu et al. & 1990 & Activation of slag cement. \\
\hline Roy et al. & 1991 & Rapid setting alkali-activated cements. \\
\hline Roy and Silsbee & 1992 & Alkali-activated cements: an overview. \\
\hline Palomo and Glasser & 1992 & CBC with metakaolin. \\
\hline Roy and Malek & 1993 & Slag cement. \\
\hline Glukhovsky & 1994 & Ancient, modern and future concretes. \\
\hline Krivenko & 1994 & Alkaline cements. \\
\hline Wang and Scivener & 1995 & Slag and alkali-activated microstructure. \\
\hline Shi & 1996 & Strength, pore structure and permeability of alkali-activated slag. \\
\hline Fernández-Jiménez and Puertas & 1997 & Kinetic studies of alkali-activated slag cements. \\
\hline Katz & 1998 & Microstructure of alkali-activated fly ash. \\
\hline Davidovits & 1999 & Chemistry of geopolymeric systems, technology. \\
\hline Roy & 1999 & Opportunities and challenges of alkali-activated cements. \\
\hline Palomo & 1999 & Alkali-activated fly ash — a cement for the future. \\
\hline Gong and Yang & 2000 & Alkali-activated red mud-slag cement. \\
\hline Puertas & 2000 & Alkali-activated fly ash/slag cement. \\
\hline Bakharev & $2001-2002$ & Alkali-activated slag concrete. \\
\hline Palomo and Palacios & 2003 & Immobilization of hazardous wastes. \\
\hline Grutzeck & 2004 & Zeolite formation. \\
\hline Sun & 2006 & Sialite technology. \\
\hline Duxson & 2007 & Geopolymer technology: the current state of the art. \\
\hline Hajimohammadi, Provis and Deventer & 2008 & One-part geopolymer. \\
\hline Provis and Deventer & 2009 & Geopolymers: structure, processing, properties and industrial applications. \\
\hline
\end{tabular}


Table 2. Chemical composition of the Portland cement.

\begin{tabular}{|c|c|c|c|c|c|c|c|c|}
\hline $\begin{array}{c}\text { Loss on } \\
\text { ignition }(\%)\end{array}$ & $\mathrm{Cl}^{-}(\%)$ & $\mathrm{SO}_{3}(\%)$ & $\begin{array}{c}\text { CaO Free } \\
(\%)\end{array}$ & $\begin{array}{c}\mathrm{CaO} \\
\text { Reactive }(\%)\end{array}$ & $\mathrm{SiO}_{2}(\%)$ & $\begin{array}{c}\mathrm{SiO}_{2}+\mathrm{Al}_{2} \mathrm{O}_{3}+ \\
\mathrm{Fe}_{2} \mathrm{O}_{3}(\%)\end{array}$ & $\operatorname{MgO}(\%)$ & $\begin{array}{c}\mathrm{Al}_{(\%)} \\
\end{array}$ \\
\hline 1.7 & 0.01 & 2.83 & 1.53 & 63.1 & 20.9 & 92.29 & 2.71 & 5.03 \\
\hline
\end{tabular}

Table 3. Chemical composition and physical properties of the fly ash

\begin{tabular}{|c|c|c|c|c|c|c|c|c|c|c|c|}
\hline $\begin{array}{l}\mathrm{Cl}^{-} \\
(\%)\end{array}$ & $\begin{array}{l}\mathrm{SO}_{3} \\
(\%)\end{array}$ & $\begin{array}{l}\mathrm{CaO} \\
\text { Free } \\
(\%)\end{array}$ & $\begin{array}{c}\mathrm{CaO} \\
\text { Reactive } \\
(\%)\end{array}$ & $\begin{array}{l}\mathrm{SiO}_{2} \\
(\%)\end{array}$ & $\begin{array}{l}\mathrm{SiO}_{2}+\mathrm{Al}_{2} \mathrm{O}_{3} \\
+\mathrm{Fe}_{2} \mathrm{O}_{3}(\%)\end{array}$ & $\begin{array}{c}\mathrm{MgO} \\
(\%)\end{array}$ & $\begin{array}{l}\mathrm{P}_{2} \mathbf{O}_{5} \\
(\%)\end{array}$ & $\begin{array}{c}\text { Total } \\
\text { alkalis } \\
(\%)\end{array}$ & $\begin{array}{c}\text { Retained on } \\
\text { No. } 325 \text { sieve } \\
(\%)\end{array}$ & $\begin{array}{l}\text { I.A. } \\
(\%)\end{array}$ & $\begin{array}{c}\text { I.A. }_{90 \mathrm{D}} \\
(\%)\end{array}$ \\
\hline 0 & 0.12 & 0.1 & 2.7 & 40.8 & 89.9 & 1.9 & 1.92 & 0.25 & 15 & 79 & 99 \\
\hline
\end{tabular}

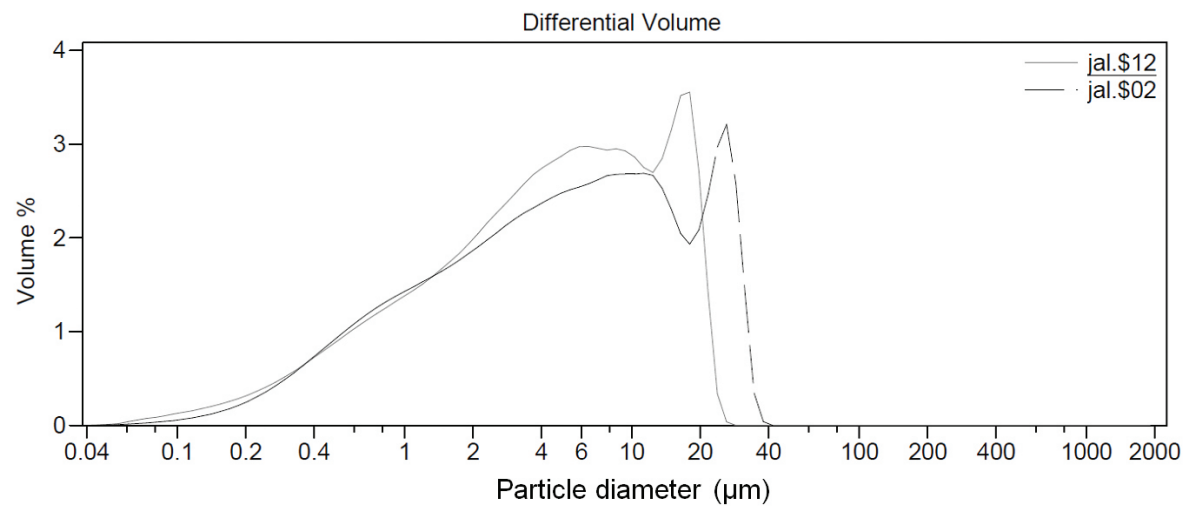

Figure 1. Kaolin particle diameter obtained with and without a deflocculating agent.

cement has $28 \%$ of $\mathrm{CaO}$ ). These results are very important because they constitute a step back in the development of geopolymers. For one, the use of hydrothermal curing implies serious limitations for on-site concrete placement operations. Alternatively, the use of calcium based mixtures reduces the acid resistance and raises the chances of ASR occurrence. All of this means that this subject merits further investigations. In 2007 some authors ${ }^{21}$ disclosed results on sodium silicate free geopolymers. However, their related mechanical performance around $1 \mathrm{MPa}$ was simply too small for construction purposes. According to those authors an increase in the compressive strength to $4 \mathrm{MPa}$ would require $24 \mathrm{~h}$ hydrothermal treatment at $100^{\circ} \mathrm{C}$. The use of a much more intensive treatment $\left(140{ }^{\circ} \mathrm{C}\right)$ would increase compressive strength to 12-20 MPa. However, such treatment conditions not only are difficult to implement in the construction industry but more important constitute a set back in terms of energy and carbon footprint when compared to traditional two part geopolymers. The discovery of onepart geopolymers is considered a key event on the evolution of geopolymer technology, having been described for the first time in 2008 (Table 1). These binders can also be termed as hybrid alkaline cements ${ }^{22,23}$. In this work, experimental mechanical results (as well as SEM and FTIR observations on these mixtures) are presented (Appendix I). The mixtures under investigation were based on the ones described in the international patent authored by Zheng et al. ${ }^{24}$.

\section{Experimental Work}

\subsection{Material}

The composition of the dry mix in this study was: kaolin, fly ash, ordinary Portland cement (OPC), sodium hydroxide, calcium hydroxide $\left(\mathrm{Ca}(\mathrm{OH})_{2}\right)$, water and superplasticizer. The OPC is of class I 42,5 R type, containing between $95 \%$ to $100 \%$ of clinker content, a specific weight of $3.15 \mathrm{~g} / \mathrm{cm}^{3}$ and a Blaine fineness of $3842 \mathrm{~cm}^{2} / \mathrm{g}$ (Table 2). The superplasticizer (SP) used was SIKA 3002 HE. The referred $\mathrm{SP}$ was used to maintain a uniform consistency throughout the different mixes. The chemical composition of the fly ash complies with the minimum requirements indicated in EN-450-1 ${ }^{[25]}$ for use as a partial replacement of cement in concrete. Based on this standard, the fly ash was categorized as class $\mathrm{B}$ and group $\mathrm{N}$ for the loss of ignition and fineness, respectively. Also, the material in question has a specific weight of $2.42 \mathrm{~g} / \mathrm{cm}^{3}$ and a chemical composition as shown in Table 3.The kaolin has a BET surface area of $21 \mathrm{~m}^{2} / \mathrm{g}$ and its particle size is shown in Figure 1, this is crucial information as this parameter influences the dehydroxylation temperature of kaolin. The DTA/TGA curves for kaolin are presented in Figure 2. A well-defined endothermic DTA peak and sharp weight loss in the TGA curve appears between $550{ }^{\circ} \mathrm{C}$ and $600{ }^{\circ} \mathrm{C}$. This loss results from the transition to the amorphous and more reactive metakaolin phase. 


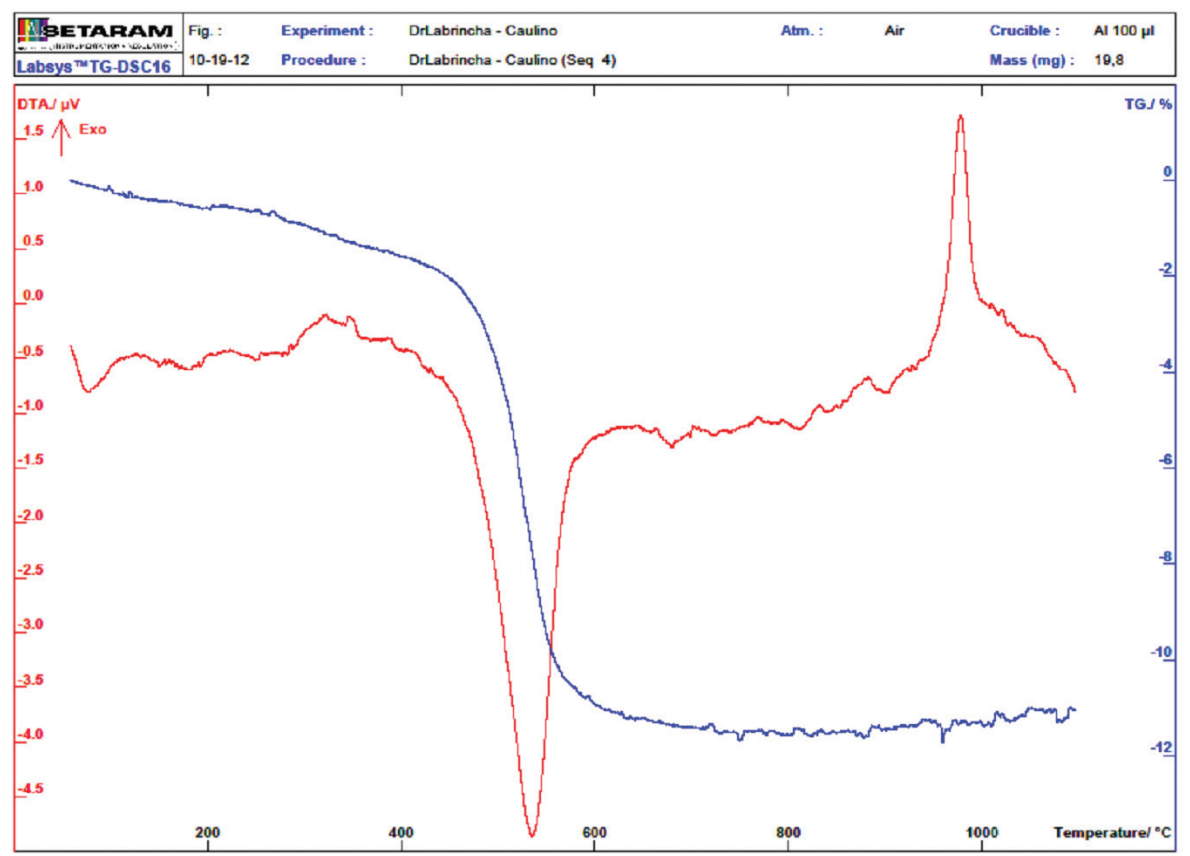

Figure 2. DTA/TGA curves for kaolin.

Table 4. Mix proportions used in phase A.

\begin{tabular}{|c|c|c|c|c|c|c|c|}
\hline Mix & $\begin{array}{l}\text { Calcined kaolin + sodium } \\
\text { or potassium hydroxide }\end{array}$ & Fly ash & OPC & $\mathrm{Ca}(\mathrm{OH})_{2}$ & $\mathbf{W} / \mathbf{b}$ & Sand(g) & SP \\
\hline $1-\mathrm{A}$ & $4 \%$ & $32.5 \%$ & $30 \%$ & $33.5 \%$ & 0.31 & ------ & ------ \\
\hline $2-\mathrm{A}$ & $4 \%$ & $58.3 \%$ & $30 \%$ & $7.7 \%$ & 0.26 & ----- & --.-- \\
\hline $3-\mathrm{A}$ & $4 \%$ & $58.3 \%$ & $30 \%$ & $7.7 \%$ & 0.34 & ----- & ----- \\
\hline $4-\mathrm{A}$ & $4 \%$ & $32.5 \%$ & $30 \%$ & $33.5 \%$ & 0.52 & 2000 & --.-- \\
\hline $5-\mathrm{A}$ & $4 \%$ & $32.5 \%$ & $30 \%$ & $33.5 \%$ & 0.34 & & ----- \\
\hline 6-A & $4 \%$ & $58.3 \%$ & $30 \%$ & $7.7 \%$ & 0.31 & & ------ \\
\hline 7-A & $4 \%$ & $58.3 \%$ & $30 \%$ & $7.7 \%$ & 0.40 & & ------ \\
\hline 8-A & $4 \%$ & $58.3 \%$ & $30 \%$ & $7.7 \%$ & 0.35 & & $0.8 \%$ \\
\hline $9-A$ & $4 \%$ & $32.5 \%$ & $30 \%$ & $33.5 \%$ & 0.37 & & $1.3 \%$ \\
\hline $10-\mathrm{A}$ & $4 \%$ & $32.5 \%$ & $30 \%$ & $33.5 \%$ & 0.35 & & $2.5 \%$ \\
\hline $11-\mathrm{A}$ & $4 \%$ & $32.5 \%$ & $30 \%$ & $33.5 \%$ & 0.31 & & $2.4 \%$ \\
\hline $12-\mathrm{A}$ & $4 \%$ & $32.5 \%$ & $30 \%$ & $33.5 \%$ & 0.36 & & $1.5 \%$ \\
\hline
\end{tabular}

Table 5. Mix proportions used in phase B.

\begin{tabular}{|c|c|c|c|c|c|c|c|}
\hline Mix & $\begin{array}{l}\text { Calcined kaolin + sodium } \\
\text { or potassium hydroxide }\end{array}$ & Fly ash & OPC & $\mathrm{Ca}(\mathrm{OH})_{2}$ & $\mathbf{W} / \mathbf{b}$ & Sand(gr) & SP \\
\hline 1-B & $3.0 \%$ & $33 \%$ & $32.2 \%$ & $33.5 \%$ & $35 \%$ & 2100 & $2.7 \%$ \\
\hline $2-B$ & $3.0 \%$ & $33 \%$ & $32.2 \%$ & $31.6 \%$ & $35 \%$ & & $2.3 \%$ \\
\hline $3-B$ & $4 \%$ & $32 \%$ & $30 \%$ & $33.5 \%$ & $35 \%$ & & 1.5 \\
\hline $4-B$ & $4 \%$ & $32.5 \%$ & $30 \%$ & $33.5 \%$ & $39 \%$ & & $1.5 \%$ \\
\hline $5-\mathrm{B}$ & $3.2 \%$ & $60 \%$ & $30 \%$ & $6.8 \%$ & $35 \%$ & & $1.0 \%$ \\
\hline $6-\mathrm{B}$ & $4 \%$ & $32.5 \%$ & $30 \%$ & $33.5 \%$ & $34 \%$ & & $1.0 \%$ \\
\hline 7-B & $4 \%$ & $58.3 \%$ & $30 \%$ & $7.7 \%$ & $30 \%$ & & $0.5 \%$ \\
\hline $8-B$ & $4 \%$ & $32.5 \%$ & $30 \%$ & $33.5 \%$ & $35 \%$ & 2200 & $1 \%$ \\
\hline 9-B & $4 \%$ & $58.3 \%$ & $30 \%$ & $7.7 \%$ & $35 \%$ & & $1 \%$ \\
\hline $10-\mathrm{B}$ & $4 \%$ & $32.0 \%$ & $30 \%$ & $33.0 \%$ & $30 \%$ & & $1 \%$ \\
\hline 11-B & $5 \%$ & $32.0 \%$ & $40 \%$ & $23.0 \%$ & $35 \%$ & & $1 \%$ \\
\hline $12-\mathrm{B}$ & $5 \%$ & $32.0 \%$ & $30 \%$ & $34.5 \%$ & $35 \%$ & & $1 \%$ \\
\hline
\end{tabular}


Table 6. Mix proportions used in phase C.

\begin{tabular}{|c|c|c|c|c|c|c|c|}
\hline Mix & $\begin{array}{c}\text { Calcined kaolin + } \\
\text { potassium hydroxide }\end{array}$ & Fly ash & OPC & $\mathrm{Ca}(\mathrm{OH})_{2}$ & $\mathbf{W} / \mathbf{b}$ & Sand(gr) & SP \\
\hline $1-\mathrm{C}$ & \multirow{4}{*}{$5 \%$} & \multirow{4}{*}{$32.0 \%$} & \multirow{4}{*}{$40 \%$} & \multirow{4}{*}{$23.0 \%$} & $34 \%$ & 2114 & $3 \%$ \\
\hline $2-\mathrm{C}$ & & & & & $34 \%$ & 2045 & $2 \%$ \\
\hline $3-C$ & & & & & $29 \%$ & 1937 & $2 \%$ \\
\hline 4-C & & & & & $30 \%$ & 1898 & $3 \%$ \\
\hline
\end{tabular}

Table 7. Phase C-Volumetric ratios.

\begin{tabular}{ccc}
\hline $\mathbf{V s} / \mathbf{V p}$ & $\mathbf{V w} / \mathbf{V} \mathbf{p}$ & $\mathbf{V s p} / \mathbf{V p}$ \\
\hline 1 & 0.77 & 0.023 \\
0.95 & 0.77 & 0.023 \\
0.9 & 0.77 & 0.023 \\
0.85 & 0.77 & 0.023 \\
\hline
\end{tabular}

\subsection{Mix proportioning and testing}

A mixture of kaolin and sodium hydroxide was calcined in a furnace at $650{ }^{\circ} \mathrm{C}$ during 140 minutes. The cooled mixture was then ground into powder. Tables 4 and 5 shows the mix proportion respectively used in phases $\mathrm{A}$ and $\mathrm{B}$. In the mixes 7 up to 12 , potassium hydroxide was used instead of sodium hydroxide. The initial phases were conceived in order to discover the mixtures with the highest compressive strength. Phases $C$ (Tables 6 and 7) and D (Tables 8 and 9) were designed to evaluate the influence of aggregate and calcium hydroxide. Tests were performed on $50 \times 50 \times 50 \mathrm{~mm}^{3}$ concrete specimens, according to NP EN $206-1^{[26]}$. The specimens were also placed in the chamber room, with relative humidity of $58 \%$, during the curing time. The compressive strength, for each mixture, was obtained from an average of the results of 3 cubic specimens. The specimens were tested at the pace of $0.36-0.72 \mathrm{~N} / \mathrm{s} . \mathrm{mm}^{2}$. The selection of the speed rate depended on the test's duration. If a test was feasible at a speed rate of $0.36 \mathrm{~N} / \mathrm{s} . \mathrm{mm}^{2}$ in 30-90 seconds, the pace was considered acceptable. But, if this pace implied a longer time frame; the pace would have to be increased up to $0.75 \mathrm{~N} / \mathrm{s} . \mathrm{mm}^{2}$. Efflorescences were evaluated by means of visual observation only. The specimens were immersed in water during 24 hours and then placed at room temperature. After 48 hours, the visualizations were recorded. For examination through scanning electron microscopy (SEM), the samples were covered with $40 \mathrm{~nm}$ film of Au-Pd (80-20 weight \%); in a high resolution sputter coater, 208HR Cressington Company, coupled to a MTM-20 Cressington High Resolution Thickness Controller. Ultrahigh resolution Field Emission Gun Scanning Electron Microscopy (FEG-SEM), NOVA 200 Nano SEM and FEI Company were also used. Backscattering Electron images were achieved through an acceleration voltage of $15 \mathrm{kV}$. Chemical analyses of samples were performed with the Energy Dispersive Spectroscopy (EDS) technique, using an EDAX Si (Li) detector with an acceleration voltage of $20 \mathrm{kV}$. The FTIR spectra were acquired in the attenuated total reflectance mode (ATR), between 4000 and $550 \mathrm{~cm}^{-1}$, using a Perkin Elmer FTIR Spectrum BX with an ATR PIKE MIRacle Specimens for FTIR study were prepared

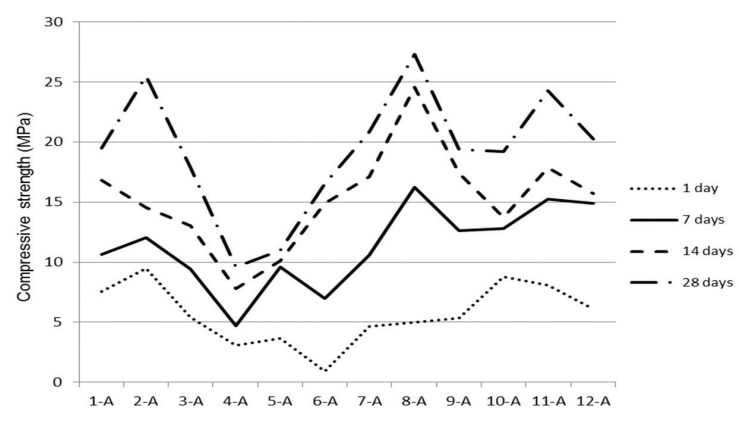

Figure 3. Compressive strength: Phase A.

by mixing $1 \mathrm{mg}$ of sample in $100 \mathrm{mg}$ of $\mathrm{KBr}$ as .suggested by Zhang et al. ${ }^{27}$. Spectral analysis was performed over the range $4000-400 \mathrm{~cm}^{-1}$ at a resolution of $4 \mathrm{~cm}^{-1}$.

\section{Results and Discussion}

\subsection{Mechanical strength results}

Figure 3 shows the compressive strength of the mixtures test in Phase A. The results show that the most promising mixture (8A) has a compressive strength of around $27 \mathrm{MPa}$ after 28 days curing. This mixture also has the eco-efficient advantage of containing a high percentage of an industrial by-product. The mixture $2 \mathrm{~A}$ shows high compressive strength performance, due to a low $\mathrm{w} / \mathrm{b}$ ratio. The results also show that, in general, curing days increases the compressive strength. This is a behaviour not observed in two part alkaliactivated cements (in which the compressive strength after just one day can reach $50 \%$ to $70 \%$ of the compressive strength after 28 days of curing $\left.{ }^{28}\right)$. However, while this behaviour is most evident for mixture $8 \mathrm{~A}$ (the one with the highest compressive strength at 14 days and at 28 days) it is not as evident for mixture 4A (which has lower fly ash content and a higher w/b). The use of a w/b=0.52 leads to compressive strength results below $12 \mathrm{MPa}$ after 28 days curing. This is a very modest performance and reveals an unsuitable mixture for use in future applications. The mixture displaying the lowest 1 day compressive strength result (6A) presents a problem of difficult explanation since it has the same composition as the mixture with the highest 28 days compressive strength (with the exception of the $\mathrm{w} / \mathrm{b}$ content which is lower). It was also observed that mixtures based on calcined kaolin and sodium hydroxide revealed lower reactivity than the mixtures in which this last constituent was replaced by potassium hydroxide. This confirms the results obtained by other authors ${ }^{29,30}$ who also found that geopolymers based on several alumino- 
Table 8. Mix proportions used in phase D.

\begin{tabular}{cccccccc}
\hline Mix & $\begin{array}{c}\text { Calcined kaolin + } \\
\text { potassium hydroxide }\end{array}$ & Fly ash & OPC & Ca(OH) & W/b & Sand(gr) & SP \\
\hline 1-D & & & $21.0 \%$ & & $2 \%$ & $1 \%$ \\
2-D & $5 \%$ & $32.0 \%$ & $40 \%$ & $24.0 \%$ & $29 \%$ & 2199 & $1 \%$ \\
3-D & & & $27.0 \%$ & & $4 \%$ \\
4-D & & & $19.0 \%$ & & \\
\hline
\end{tabular}

Table 9. Phase D-Weight ratios.

\begin{tabular}{cccc}
\hline $\mathbf{W C a}(\mathrm{OH})_{2} / \mathbf{W c}$ & $\mathbf{W C a} / \mathbf{W c}$ & $\mathbf{W F A} / \mathbf{W c}$ & WSP/Wc \\
\hline 0.45 & 0.12 & 0.79 & 0.01 \\
0.5 & 0.12 & 0.79 & 0.01 \\
0.65 & 0.12 & 0.79 & 0.01 \\
0.7 & 0.12 & 0.79 & 0.01 \\
\hline
\end{tabular}

silicate minerals showed higher compressive strength in $\mathrm{KOH}$ than in $\mathrm{NaOH}$. This fact is, however, independent of the extent of dissolution being that those minerals display higher dissolution when $\mathrm{NaOH}$ is used.Figure 4 shows the compressive strength of the mixtures test in Phase B. The results indicate that a higher compressive strength mixture was obtained (11B) as it reached $30 \mathrm{MPa}$ after 28 days curing. Environmentally speaking, since this mixture possesses $10 \%$ more OPC and $15 \%$ more calcium hydroxide, it seems that it is as eco-efficient as the previous mixture (8A). An interesting behaviour can be observed when comparing the mixture $11 \mathrm{~B}$ with mixture 10B. The differences between the two reside in the fact that mixture $10 \mathrm{~B}$ includes $10 \%$ less OPC but $10 \%$ more calcium hydroxide, and also, that it has a low w/b. As a consequence, its compressive strength after 28 days curing is almost $10 \mathrm{MPa}$ apart from mixture $11 \mathrm{~B}$, and probably, if the $w / b$ was the same, the compressive strength difference could be even higher. This suggests the existence of very reactive constituents in OPC. Again, the mixtures where sodium hydroxide was replaced by potassium hydroxide show higher compressive strength. Figure 5 illustrates the compressive strength of the mixtures test in Phase $\mathrm{C}$. In this phase, the mixture $11 \mathrm{~B}$ was used as reference in order to evaluate the compressive strength variation due to aggregate content. Vs relates to the volume of sand and Vp to the volume of powder (OPC, FA, Kaolin, potassium hydroxide and $\left.\mathrm{Ca}(\mathrm{OH})_{2}\right)$. Increasing the sand content leads to lower compressive strength, this happens because the $\mathrm{w} / \mathrm{b}$ ratio also increases. Figure 6 shows the compressive strength of the mixtures tested in Phase D. In this phase, the mixture 11B was used as reference in order to evaluate the compressive strength variation due to calcium hydroxide content. The calcium hydroxide is presented as a function of the Portland cement percentage. The results show that there is not a direct linear relationship between the calcium hydroxide content and the compressive strength. The use of calcium hydroxide percentages of as much as $50 \%$ of Portland cement leads to the highest compressive strength. Increasing the $\mathrm{Ca}(\mathrm{OH})_{2}$ content beyond that percentage can lead to a decrease in the compressive strength.

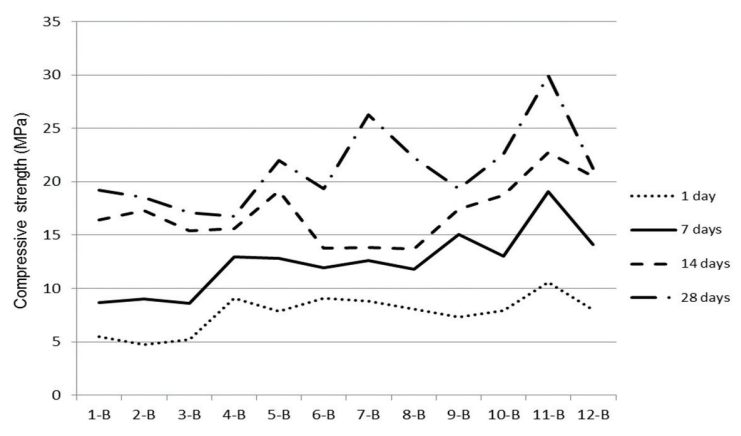

Figure 4. Compressive strength: Phase B.

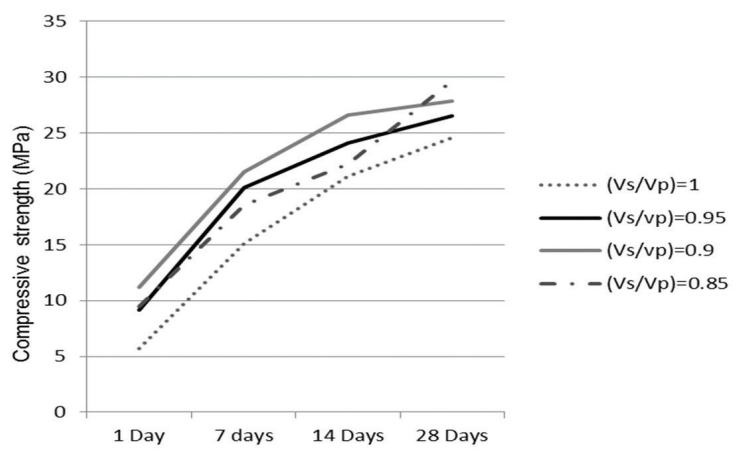

Figure 5. Compressive strength: Phase C.

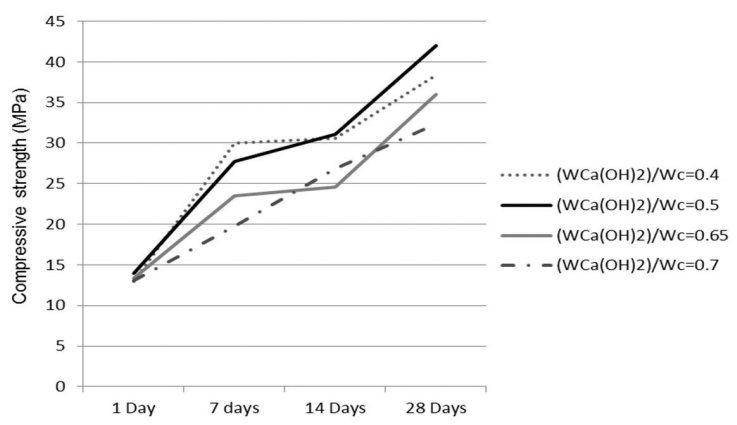

Figure 6. Compressive strength: Phase D.

\subsection{Scanning electron microscopy analysis}

Figures 7 and 8 show two SEM micrographs of mixture $8 \mathrm{~A}$ (the one with highest strength). In contrast with the typical porous interfacial transition zone of Portland cement mixtures, hybrid alkaline cement mortars present 


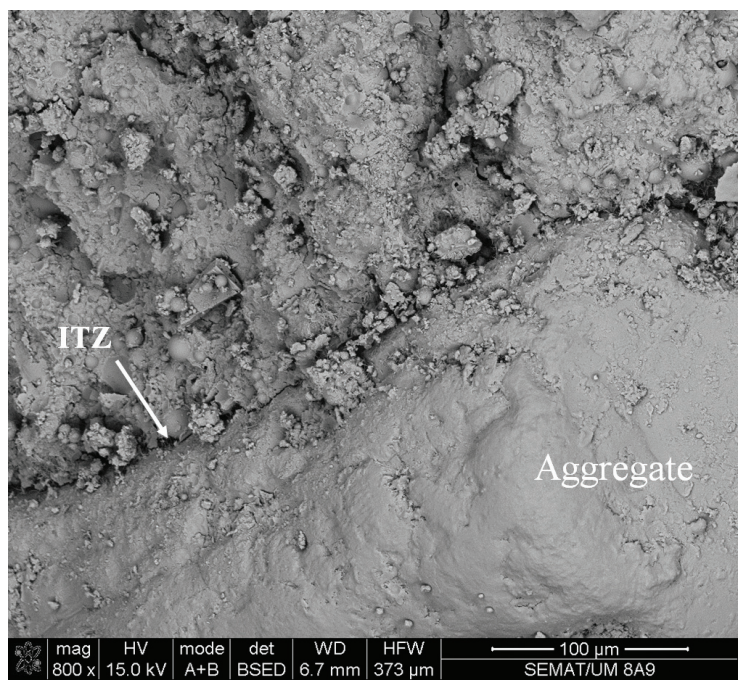

Figure 7. SEM micrograph of interfacial transition zone.

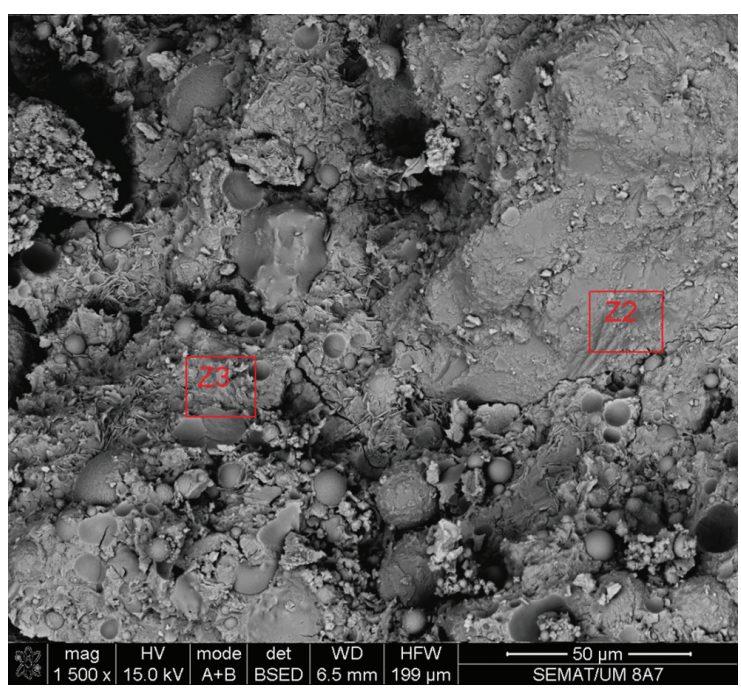

Figure 8. SEM micrograph of hybrid alkaline cement mortar.

a very dense and uniform ITZ. The molar ratios of the analyses carried out by EDS are displayed in Table 10. Typical C/S ratios in CSH of traditional OPC systems are situated from 1.5 to $2.0^{[31,32]}$. However, the areas $\mathrm{Z} 2$ and $\mathrm{Z} 3$ present a much lower $\mathrm{C} / \mathrm{S}$ ratio meaning there has been some sodium replacing $\mathrm{Ca}^{2+}$ in $\mathrm{CSH}$. Some authors have already demonstrated that sodium incorporation in the $\mathrm{CSH}$ phase increases as $\mathrm{C} / \mathrm{S}$ ratio decreases, and therefore, label it a Na-C-S-H gel ${ }^{33}$. The areas marked as Z2 and Z3 are identified as some form of calcium silicate with traces of some sodium and aluminum in its composition, which could be associated to a (N,C)-A-S-H gel. According to Garcia-Lodeiro et al. ${ }^{34,35}$, these gels usually evolve into compositions with higher calcium and lower aluminum content (with the $\mathrm{C}-\mathrm{A}-\mathrm{S}-\mathrm{H}$ gel proposed to be more stable than $\mathrm{N}-\mathrm{A}-\mathrm{S}-\mathrm{H}$, at high $\mathrm{pH}$ ). Those authors also mention that this is a blank field and that almost nothing has been published concerning the interaction between
Table 10. EDS Atomic ratio analysis.

\begin{tabular}{lcc}
\hline \multirow{2}{*}{ Atomic ratio } & \multicolumn{2}{c}{ Zone } \\
\cline { 2 - 3 } & $\mathbf{Z 2}$ & $\mathbf{Z 3}$ \\
\hline $\mathrm{SiO}_{2} / \mathrm{Al}_{2} \mathrm{O}_{3}$ & 25.6 & 2.89 \\
$\mathrm{Al}_{2} \mathrm{O}_{3} / \mathrm{Na}_{2} \mathrm{O}$ & 2.15 & 5.44 \\
$\mathrm{CaO} / \mathrm{SiO}_{2}$ & 0.13 & 0.5 \\
$\mathrm{Na} 2 \mathrm{O} / \mathrm{CaO}$ & 0.13 & 0.12 \\
$\mathrm{MgO} / \mathrm{Al}_{2} \mathrm{O}_{3}$ & - & 0.15 \\
\hline
\end{tabular}

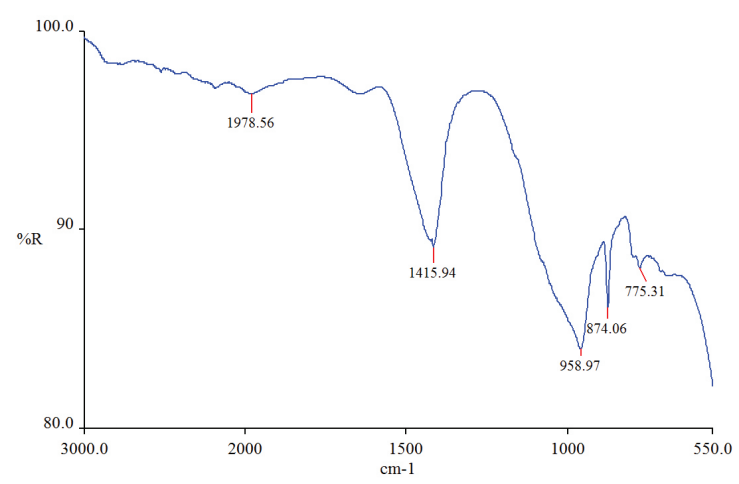

Figure 9. FTIR spectra.

aluminosilicate materials containing sodium (or potassium or sulphates) in the formation of N-A-S-H or K-A-S-H type cementitious gels.

\subsection{FTIR spectra}

The FTIR spectra of the mixture with the highest compressive strength (phase A) is presented in Figure 9. The strong peak band $965 \mathrm{~cm}^{-1}$ is characterized as asymmetric $\mathrm{Si}-\mathrm{O}-\mathrm{Si}$ or Al-O-Si stretching, which is typical of the polymerization of the silicate group with the formation of CSH.A medium band at $774 \mathrm{~cm}^{-1}$ is formed by a network of $\mathrm{Si}-\mathrm{O}-\mathrm{Si}$ stretching. The carbonate bands at around $1415 \mathrm{~cm}^{-1}$ arise from the reactions of atmospheric $\mathrm{CO}_{2}$ with calcium hydroxide. This peak intensity changes with the amount of calcium hydroxide. The broad bands in the region of $1648-3466 \mathrm{~cm}^{-1}$ characterized the spectrum of stretching and deformation vibrations of $\mathrm{O}-\mathrm{H}$ and $\mathrm{H}-\mathrm{O}-\mathrm{H}$ groups from the weakly bound water molecules (which were adsorbed on the surface or trapped in the large cavities between the rings of alkaline aluminosilicate products).

\subsection{Efflorescences}

Concerning the occurrence of efflorescences, no presence was observed. This confirmed the observations included in the international related patent ${ }^{24}$. The explanations for that can be related to the low amount of (sodium/potassium) as well as to the fact that some sodium/potassium replaced $\mathrm{Ca}^{2+}$ in $\mathrm{CSH}$ hydration products. Another factor that influences efflorescences is pore volume and permeability. In Portland cement, the water participates in the hydration products so, as the hydration progresses, the pore volume decreases over time. However, two part alkali-activated binders do not 
have the same pore volume reduction benefit through the conversion of water into a solid via its incorporation into reaction products ${ }^{17}$, thus needing a very low $\mathrm{w} / \mathrm{b}$ ratio to ensure low permeability.

\section{Conclusions}

This study has conducted preliminary experimental investigations on the mechanical performance of hybrid alkaline cement mixtures. Based on the experimental results, the following conclusions can be drawn: a compressive strength of $27 \mathrm{MPa}$ after 28 curing days was achieved through the use of a mixture containing only $30 \%$ OPC. Also, a general trend was observed linking compressive strength evolution to curing age (which is typical of OPC chemistry). Additionally, mixtures based on calcined kaolin and sodium hydroxide revealed lower reactivity than the mixtures in which this

\section{References}

1. Juenger M, Winnefeld F, Provis J and Ideker J. Advances in alternative cementitious binders. Cement and Concrete Research. 2011; 41:1232-1243. http://dx.doi.org/10.1016/j. cemconres.2010.11.012

2. Damtoft J, Lukasik J, Herfort D, Sorrentino D and Gartner E. Sustainable development and climate change initiatives. Cement and Concrete Research. 2008; 38:115-127. http:// dx.doi.org/10.1016/j.cemconres.2007.09.008

3. Pacheco-Torgal F. Introduction. In Pacheco Torgal F, Jalali S, Labrincha JA and John VM, editors. Eco-efficient concrete. Cambridge: Woodhead Publishing Limited Abington Hall; 2013.

4. Pacheco-Torgal F, Castro-Gomes J and Jalali S. Alkali-activated binders: a review Part 1 Historical background, terminology, reaction mechanisms and hydration products. Construction and Building Materials. 2008; 22:1305-1314. http://dx.doi. org/10.1016/j.conbuildmat.2007.10.015

5. Pacheco-Torgal F, Castro-Gomes $\mathrm{J}$ and Jalali S. Alkali - activated binders: a review Part 2 About materials and binders manufacture. Construction and Building Materials. 2008; 22:1315-1322. http://dx.doi.org/10.1016/j. conbuildmat.2007.03.019

6. Li C, Sun H and Li L. A review: The comparison between alkali-activated slag $(\mathrm{Si}+\mathrm{Ca})$ and metakaolin $(\mathrm{Si}+\mathrm{Al})$ cements. Cement and Concrete Research. 2010; 40:1341-1349. http:// dx.doi.org/10.1016/j.cemconres.2010.03.020

7. Pacheco-Torgal F, Abdollahnejad Z, Miraldo S, Baklouti S and Ding Y. An overview on the potential of geopolymers for concrete infrastructure rehabilitation. Construction and Building Materials. 2012; 36:1053-1058. http://dx.doi. org/10.1016/j.conbuildmat.2012.07.003

8. Pacheco-Torgal F, Ding Y, Miraldo S, Abdollahnejad Z and Labrincha J. Are geopolymers more suitable than Portland cement to produce high volume recycled aggregates HPC? Construction and Building Materials. 2012; 32:1048-1052. http://dx.doi.org/10.1016/j.conbuildmat.2012.07.004

9. Davidovits J, Comrie D, Paterson J and Ritcey D. Geopolymeric concretes for environmental protection. ACI Concrete International. 1990; 12:30-40.

10. Duxson P, Provis J, Luckey G and Van Deventer J. The role of inorganic polymer technology in the development of "Green last constituent was replaced by potassium hydroxide. Furthermore, the results show that there is not a direct linear relationship between the calcium hydroxide content and the compressive strength. None of the mixtures showed any signs of efflorescences. The explanation for this phenomenon can reside in the low amount of sodium/ potassium used, as well as in the fact that some sodium and potassium may have replaced calcium in the hydration products. Hybrid alkaline cement mortars presented a very dense and uniform ITZ. No traditional porous interfacial transition zone was detected in these binders.Further investigations on mixture composition are also needed in order to select mixtures with high compressive strength and high fly ash content. Furthermore, analysis of durability parameters is also needed. Evaluation of LCA of hybrid alkaline cements also merits further investigations to confirm their eco-efficiency.

Concrete". Cement and Concrete Research. 2007; 37:15901597. http://dx.doi.org/10.1016/j.cemconres.2007.08.018

11. Duxson P and Van Deventer J. Commercialization of geopolymers for construction-opportunities and obstacles. In: Provis J and Van Deventer J, editors. Geopolymers, Structure, Processing, Properties and Applications. Cambridge: Woodhead Publishing Limited Abington Hall; 2009. PMid:20092553.

12. Weil M, Dombrowski K and Buchawald A. Life-cycle analysis of geopolymers. In: Provis J and Van Deventer J, editors. Geopolymers, Structure, Processing, Properties and Applications. Cambridge: Woodhead Publishing Limited Abington Hall; 2009. p. 194-210.

13. McLellan B, Williams R, Lay J, Van Riessen A and Corder G. Costs and carbon emissions for geopolymer pastes in comparison to ordinary Portland cement. Journal of Cleaner Production. 2011; 19:1080-1090. http://dx.doi.org/10.1016/j. jclepro.2011.02.010

14. Habert G, De Lacaillerie J and Roussel N. An environmental evaluation of geopolymer based concrete production: reviewing current research trends. Journal of Cleaner Production. 2011; 11:1229-1238. http://dx.doi.org/10.1016/j. jclepro.2011.03.012

15. Pacheco-Torgal F, Abdollahnejad Z, Camões A, Jamshidi M and Ding Y. Durability of alkali-activated binders. A clear advantage over Portland cement or an unproven issue?. Construction and Building Materials. 2012; 30:400-405. http://dx.doi. org/10.1016/j.conbuildmat.2011.12.017

16. Provis J, Muntingh Y, Lloyd R, Xu H, Keyte L, Lorenzen $\mathrm{L}$ et al. Will geopolymers stand the test of time?. Ceramic Engineering and Science Proceedings. 2008; 28:235-248.

17. Van Deventer J, Provis J and Duxson P. Technical and commercial progress in the adoption of geopolymer cement. Minerals Engineering. 2012; 29:89-104. http://dx.doi. org/10.1016/j.mineng.2011.09.009

18. Skvara F, Kopecky L, Smilauer V, Alberovska L and Bittner Z. Material and structural characterization of alkali activated low-calcium brown coal fly ash. Journal of Hazardous Materials. 2008; 168:711-720. PMid:19303704. http://dx.doi. org/10.1016/j.jhazmat.2009.02.089 
19. Skvara F, Kopecky L, Smilauer V, Alberovska L and Vinsova L. Aluminosilicate polymers - Influence of elevated temperatures, efflorescence. Ceramics - Silikaty. 2009; 53:276-282.

20. Kani E, Allahverdi A and Provis J. Efflorescence control in geopolymer binders based on natural pozzolan. Cement and Concrete Composites. 2011; 34:25-33. http://dx.doi. org/10.1016/j.cemconcomp.2011.07.007

21. Kolousek D, Brus J, Urbanova M, Andertova J, Hulinsky V and Vorel J. Preparation, structure and hydrothermal stability of alternative (sodium silicate free) geopolymers. Journal of Materials Science. 2007; 42, 9267-9275. http://dx.doi. org/10.1007/s10853-007-1910-5

22. Shi C, Fernandez-Jimenez A and Palomo A. New cements for the 21st century: The pursuit of an alternative for Portland cement. Cement and Concrete Research. 2011; 41:750-763. http://dx.doi.org/10.1016/j.cemconres.2011.03.016

23. Garcia-Lodeiro I, Fernandez-Jimenez A and Palomo A. Variation in hybrid cemnts over time. Alkaline activation of fly ash-portland cement blends. Concrete Research. 2013; 52:112122. http://dx.doi.org/10.1016/j.cemconres.2013.03.022

24. Zheng D, Van Deventer JSL and Duxson P. The dry mix cement composition, methods and systems involving same. International Patent WO 2007/109862 A1; 2007.

25. NORMA EUROPEIA. NP EN 450-1: Fly ash for concrete - Part 1: Definition, specifications and conformity criteria. 2005.

26. NORMA EUROPEIA. NP EN 206-1: 2007: Concrete: Part 1. Specification, performance, production and conformity. 2007.

27. Zhang M, Wruck B, Graeme-Barber A, Salje E and Carpenter M. Phonon-spectroscopy on alkali-feldspar: phase transitions and solid solutions. American Mineralogist. 1996; 81:92-104.
28. Pacheco-Torgal F, Castro-Gomes JP and Jalali S. Investigations about the effect of aggregates on strength and microstructure of geopolymeric mine waste mud binders. Cement and Concrete Research. 2007; 37:933-941. http://dx.doi.org/10.1016/j. cemconres.2007.02.006

29. $\mathrm{Xu} \mathrm{H}$ and Van Deventer JSJ. The geopolymerisation of alumino-silicate minerals. International Journal of Mineral Processing. 2000; 59:247-266. http://dx.doi.org/10.1016/ S0301-7516(99)00074-5

30. $\mathrm{Xu} \mathrm{H}$. The geopolymerisation of alumino-silicate minerals [thesis]. University of Melbourne; 2002.

31. Diamond S. C/S mole ratio of $\mathrm{CSH}$ gel in a mature $\mathrm{C} 3 \mathrm{~S}$ paste as determined by EDXA. Cement and Concrete Research. 1976; 6:413-416. http://dx.doi.org/10.1016/00088846(76)90105-8

32. Richardson IG. The nature of the hydration products in hardened cement pastes. Cement and Concrete Composites. 2000; $22: 97-$ 113. http://dx.doi.org/10.1016/S0958-9465(99)00036-0

33. MacPhee DE. Solubility and aging of calcium silicate hydrates in alkaline solutions at $25{ }^{\circ} \mathrm{C}$. Journal of American Ceramic Society. 1989; 72:646-654. http://dx.doi. org/10.1111/j.1151-2916.1989.tb06189.x

34. Garcia-Lodeiro I, Palomo A, Fernández-Jiménez A and MacPhee DE. Compatibility studies between $\mathrm{N}-\mathrm{A}-\mathrm{S}-\mathrm{H}$ and $\mathrm{C}-\mathrm{A}-\mathrm{S}-\mathrm{H}$ gels. Study in the ternary diagram $\mathrm{Na}_{2} \mathrm{O}-\mathrm{CaO}-\mathrm{Al}_{2} \mathrm{O}_{3}-\mathrm{SiO}_{2}-$ $\mathrm{H}_{2} \mathrm{O}$. Cement and Concrete Research. 2011; 41(9):923-931. http://dx.doi.org/10.1016/j.cemconres.2011.05.006

35. Garcia-Lodeiro, Fernandez-Jimenez, A, Palomo, A. Alkaliactivated based concrete. In: Pacheco-Torgal F, Jalali S, Labrincha J and John VM, editors. Eco-efficient concrete. Cambridge: Woodhead Publishing Limited Abington Hall; 2013. p. 439-487.

Appendix 1. Abbreviations and acronyms.

\begin{tabular}{ll}
\hline OPC & Ordinary Portland cement \\
FA & Fly ash \\
SP & Superplasticizer \\
DTA & Differential thermal analysis \\
TGA & Thermogravimetric analysis \\
SEM & Scanning Electron Microscopy \\
FEG & Field Emission Gun \\
EDS & Energy Dispersive Spectroscopy \\
ITZ & Interfacial transition zone \\
FTIR & Fourier transform infrared spectroscopy \\
CSH & Calcium silicate hydrates \\
Na-C-S-H & Sodium calcium silicate hydrates \\
N-A-S-H & Sodium aluminum silicate hydrates \\
K-A-S-H & Potassium aluminum silicate hydrates \\
\hline
\end{tabular}

